\title{
SONHOS DE 68: SEXO, CINEMA E... REVOLUÇÃO?
}

DREAMS OF 68: SEX, MOVIE THEATER AND... REVOLUTION?

\section{Cesar Augusto Barcellos Guazzelli', Charles Sidarta Machado Domingos², José Orestes Beck ${ }^{3}$, Rafael Hansen Quinsani ${ }^{4}$, Sandro Gonzaga ${ }^{5}$}

RECEBIDO: 27/03/2018 | ACEITO: 24/05/2018

DOI: $10.5902 / 2317175831852$

\section{RESUMO}

Este artigo aborda a visão contemporânea da sociedade sobre os eventos do ano de 1968. Para tanto, utilizamos como fonte o filme Os Sonhadores, de Bernardo Bertolucci. Em nossa análise, destacamos a interlocução do elemento fílmico com o contexto de 1968 - tanto na França como na sua relação com os Estados Unidos. Além disso, procuramos relacionar a película com a música e a produção cinematográfica representada na obra analisada.

Palavras-chave: 1968; Os Sonhadores; História e Cinema

1Doutor em História pela UFRJ. Professor Titular do Departamento e do PPG em História da UFRGS.

2Doutor em História pela UFRGS. Professor de História no Instituto Federal Sul-rio-grandense (IFSUL) - Câmpus Charqueadas.

3Licenciado e Bacharel em História pela UFRGS. Professor de História na Prefeitura Municipal de Tapes. 4Doutor em História pela UFRGS.

5Mestre em História pela UFRGS 


\begin{abstract}
This article approaches the contemporary view of society on the events of the year 1968. To do so, we use Bernardo Bertolucci's film The Dreamers as a source. In our analysis, we highlight the interlocution of the film element with the context of 1968 - both in France and in its relationship with the United States. In addition, we try to relate the film to the music and the cinematographic production represented in the work analyzed.
\end{abstract}

Keywords: 1968; The Dreamers; Cinema-History

\title{
1 Introdução
}

1968 é um ano emblemático para os historiadores. Muitas são as controvérsias a respeito da extensão de seus acontecimentos; contudo, em um ponto há relativo consenso: 68 representa a contestação ao mundo em que se vivia. E que mundo era esse? No plano mais geral, era o mundo da Guerra Fria, onde se confrontavam dois sistemas econômico-sociais: o capitalismo e o socialismo. Em um sentido mais estrito, era um mundo ainda marcado por uma sociedade conservadora no plano das relações sexuais e afetivas.

Cinquenta anos depois, em muitos aspectos, o mundo mudou drasticamente; em outros, as permanências são visíveis, em maior ou menor grau. Mas qual a visão contemporânea da sociedade sobre os eventos do ano de 1968? Questão complexa e de difícil resolução. Complexa pela própria dinâmica da sociedade que não pode ser entendida como um bloco monolítico - muitas são as suas divisões. De difícil resolução, principalmente, em razão do "profundo desconhecimento e mistificação sobre o que foi 68 e sobre a sua complexidade e amplitude; o desconhecimento sobre o seu significado histórico; sobre as suas raízes e seu processo; mas, também, o desconhecimento dos seus efeitos históricos" (RIBEIRO, 2003, p. 121).

Uma forma de nos aproximarmos dessa visão contemporânea sobre o 68 pode ser buscada através do Cinema - pela forma como este representa os eventos daquele ano símbolo. Para tanto, nos valeremos, neste trabalho coletivo, do filme Os Sonhadores (The Dreamers), produção ítalo-britânicofrancesa de 2003, dirigida por Bernardo Bertolucci, baseada no romance The Holy Innocents, de Gilbert Adair - que foi o roteirista do filme.

Segundo o diretor, a película teve por objetivo primordial o resgate do movimento de Maio de 1968 na França, devido a opiniões recentemente divulgadas de que ele havia fracassado (BERTOLUCCI, O Estado de São Paulo, 2004). Contextualizar essa afirmação à luz da História é tarefa instigante; demonstrar os limites e contradições da abordagem cinematográfica em questão se configura como fundamental para o aprofundamento do conhecimento e a desmistificação sobre o ano de 1968. 


\section{Americano em Paris}

Os Sonhadores é uma visão contemporânea sobre os acontecimentos de maio de 1968 em Paris. Já no início do filme, o estadunidense Mathew, ao narrar que em 1968 tinha 20 anos e estava em Paris, para estudar francês, aproxima os espectadores de uma lembrança sua, vista em retrospectiva. Dessa maneira, há um vínculo estabelecido pelo compartilhamento da experiência de quem conta a história - alguém representado pelo personagem Mathew - com quem quem a recebe - os espectadores do século XXI. Embora a narrativa inicie e temine com a Revolução tomando conta das ruas de Paris no maio de 1968, o enredo - e portanto a narrativa - no entanto, se passa quase todo entre paredes, centrado na relação entre ele próprio (Mathew) e os seus irmãos, Isabelle e Theo.

Isso é possível em razão da seletividade da memória: ao valorizar determinados elementos - lembranças - outros são esquecidos. Na película de Bertolucci, pouco se fala sobre o próprio país de Mathew e as condições que podem ter gerado seu "exílio voluntário", o que acabou livrando-o das turbulências que atingiam os Estados Unidos: a questão racial atingira aparentemente seu clímax com o assassinato de Martin Luther King em 4 de abril, retirando do cenário político uma liderança moderada e pacifista, jogando o ativismo pelos direitos civis nas mãos mais radicais, como os Panteras Negras. Do mesmo modo esquece-se que no Vietnã do Sul, desde 30 de janeiro, assistiase a chamada "ofensiva do Tet", quando os vietcongs apoiados pelo exército do Vietnã do Norte, atacaram posições dos Estados Unidos e avançaram sobre diversas cidades, ocupando a antiga capital imperial Huê, e a própria embaixada dos Estados Unidos, em Saigon. Os protestos pela igualdade racial se confundiam com as passeatas pela retirada das forças armadas estadunidenses do Sudeste Asiático; interna e externamente, a grande potência ocidental mostrava suas fraquezas e, não por acaso, Mao Tse Tung, o "grande timoneiro" da Revolução Chinesa - e um dos ícones prediletos dos jovens rebelados em Paris - se referia aos Estados unidos como um "tigre de papel".

Neste ambiente de dúvidas e ceticismo, impensável nos anos seguintes à Segunda Guerra, muitos estudantes estadunidenses recusavam-se a defender o país, fugindo às convocações para o serviço militar no Vietnã. Como a maior parte dos convocados era formada por negros, os ativistas dos direitos civis minavam os discursos patrióticos, alertando para os desequilíbrios internos: porque afrodescendentes tinham que matar asiáticos na defesa de valores da sociedade branca e racista? Aqueles que podiam, buscavam refugiar-se no Canadá ou nos países europeus, sendo que Paris tornou-se uma referência importante.

Mathew não era um caso isolado, e não foi casual a presença desse personagem na trama. Indícios disso podem ser vislumbrados quando ele começa a escrever uma carta para sua mãe, onde se lê: espero que papai não continue zangado comigo. Em uma sociedade belicista como a dos Estados Unidos, não é difícil imaginar que para muitos - e o pai do personagem pode ser um deles - 
não ir à guerra se constitua um motivo forte de irritação; outro indício pode ser associado ao seu medo pela deportação, quando os irmãos parisienses propõem uma pequena transgressão no Museu do Louvre. Porque esse medo de voltar a seu país? A ambigüidade do estadunidense da Costa Oeste-palco de importantes atividades contra a Guerra do Vietnã -, portador de ideais pacifistas, mas nada fazendo para o fim da guerra, chega ao seu ponto máximo na cena da em que divide a banheira com Theo e, em acalorada discussão, este questiona: Você não devia estar no Vietnã?. Ao reforçar esse argumento - verdadeiro e objetivo -, mas sem fazer referências aos grandes movimentos pela paz, qual a visão que o diretor Bernardo Bertolucci acaba passando para os contemporâneos do século $\mathrm{XXI}$, que pouco sabem sobre o ano de 68 ?

\section{A Sexualidade e a Música d'Os Sonhadores}

O filme conta a história de três amigos que partem em uma jornada cinéfila e sensual. $O$ tema sexualidade e música transpassa permanentemente a película: jovens de aproximadamente 20 anos, estão descobrindo os prazeres carnais da vida, a paixão pelo cinema e pela música.

Assim, o filme começa ao som da eletrizante música Third Stone from the Sun, de Jimi Hendrix, enquanto Mathew se desloca até a Cinemathéque Française, onde conhece Isabelle e seu irmão Theo nos protestos contra a demissão do diretor desta instituição. Este, logo se diz apaixonado pelos novos amigos, com os quais discutia política, cinema, a falta de um grupo de rock'n'roll francês...

O encontro propicia a oportunidade para se conhecerem melhor: Theo resolve convidar o amigo para jantar em seu apartamento, onde Mathew começa a achar estranho o tipo de relacionamento que seus amigos nutrem entre si e sua família. O jovem estadunidense fica perplexo com a maneira como o pai de Isabelle a toca e como ela se despede do irmão antes de deitar: um beijo na boca.

O jantar também traz à tona um assunto que aparecerá no filme, porém em menor escala: o conflito de gerações. Theo diz não querer ficar igual ao pai, após uma discussão sobre a visão que ele tem de como as mudanças na sociedade devem ser feitas. A cena se encerra ao embalo de Janis Joplin, com a música I Need a Man to Love, faixa do disco Cheap Thrills, de 1968, época em que ela cantava com o Big Brother \& The Holding Company.

Após o jantar, Mathew é convidado para dormir no apartamento dos amigos; no aposento onde ficará há uma reprodução do quadro $A$ Liberdade Guiando os Povos, de Eugène Delacroix, na qual o rosto da personagem principal é trocado pelo de Marylin Monroe, uma ligação ao Cinema que tanto amam como também uma referência ao erotismo, como se o diretor quisesse dizer que está substituindo o caráter político que o filme pretendia ter, pelo caráter sensual. 
Mathew, após um pesadelo, procura o banheiro e vê os dois irmãos nus dormindo juntos - o que lhe causa ainda mais estranheza. Pela manhã, ele é acordado por Isabelle que "tira o sono" de seus olhos como faz com Theo. Isso exprime o grau de intimidade que ele está adquirindo. Ele também é todo pudico, dizendo não estar vestido, enquanto Isabelle tenta descobrilo - contraponto ao modo dos irmãos que se trocam e se desnudam a todo tempo a sua frente. É importante destacar que a relação de Theo e Isabelle é a todo momento apresentada à Mathew através de um reflexo no espelho, uma janela ou porta entreaberta. O significado desses artifícios é a representação do choque da cultura estadunidense com a européia, pois, ao mesmo tempo que essa diferença os separa, ela também amplia o interesse de um pelo outro - curiosidade tipicamente associada à juventude. Esse interesse é mútuo; já estava presente desde antes de se apresentarem um aos outros, como fica expresso nas conjecturas de Isabelle e Theo a respeito do "forasteiro". Fica ainda mais patente quando, no banheiro, enquanto os três se lavam, Mathew é convidado a sair da pensão onde se hospedava para ir morar com Theo e Isabelle. Nisto, ela diz que o amigo tem lábios lindos e os toca, expressando mais uma referência sensual do filme.

No quarto de Theo, eles discutem quem é melhor comediante Buster Keaton (estadunidense) ou Charles Chaplin (europeu - inglês), ao som de Ball and Chain, de Janis Joplin, que Isabelle insiste em colocar para tocar repetidamente, causando a ira de Theo. A seguir, numa primeira charada cinematográfica, Mathew tem seus conhecimentos de cinéfilo postos à prova, com uma cena de $O$ Picolino (de Mark Sandrich, 1935). Após acertar, o rapaz é incitado a outra prova: representarem juntos uma cena de Bande à Part, em que três jovens correm pelas galerias do Louvre, havendo a necessidade de ser quebrada a marca exibida no filme. Desafio concluído e com a marca batida, Mathew é definitivamente aceito ao convívio dos irmãos.

Voltando ao apartamento, andam na chuva, ao som de Queen Jane Approximately interpretada por Bob Dylan. Com isso, os três "mergulhariam" definitivamente num jogo de sedução e luxúria: jogos se sucedem, confrontando conhecimentos de Cinema com a audácia de pagar os castigos impostos pelos vencedores. Theo é desafiado a acertar a cena do filme $A$ Vênus Loira (Blonde Vênus, de Josef von Sternberg, 1932) que Isabelle interpreta. Ele erra e é penalizado, tendo que se masturbar em frente a uma foto da protagonista do filme Marlene Dietrich e na presença de Mathew e Isabelle.

Agora é a vez de Theo proferir o próximo enigma, utilizando uma cena de Scarface - A vergonha de uma nação (Scarface - The shame of the nation, de Howard Hawks, 1932). Ele diz que o americano também deveria participar. Este, surpreso pergunta "O que eu fiz?" Theo dá por encerrada a competição e diz que os dois deveriam pagar a prenda. Mathew e Isabelle deveriam transar em frente ao quadro de Delacroix para uma reprodução inspirar a outra. Nisso Isabelle começa uma dança sensual, quase um strip-tease, ao som de $L a$ 
Mer, de Albert Lasry e Charles Trenet. Apavorado, Mathew foge do quarto para a cozinha, onde é encurralado por Theo. Isabelle chega com suas formas exuberantes à mostra e com a ajuda de Theo tira as roupas de Mathew. Ao desnudar Mathew por completo, ela encontra uma foto sua junto ao pênis do rapaz e, maliciosamente, diz a ele: vejo que você me leva perto de seu coração.

Os dois transam então no chão da cozinha; Mathew completamente sem jeito - pois era virgem -, começa a penetrar Isabelle. Após o ato, Theo toca na vagina da irmã, que estava ensangüentada. Neste momento, percebese que Isabelle também era virgem. Merece destaque que, à medida em que esses jogos "esquentavam", não receberam do estadunidense quaisquer recriminações; depois da tórrida cena - presenciada despudoradamente por Theo -, Mathew aceita participar de todas as relações incestuosas dos dois irmãos e aquelas de ménage a trois, o que seria improvável para um jovem recém chegado e ainda portador dos tabus da sociedade estadunidense dos anos sessenta. Aqui, de forma indireta, prenunciava-se a disseminação desta feroz rebeldia antiburguesa para os até então comportados Estados Unidos; mais tarde, a contracultura daquele país - bem representada pelo movimento hippie - se encarregaria, até mais que os irrequietos estudantes franceses, de recusar os valores tradicionais que incensavam pátria, família e religião. Mathew, o americano em Paris, poderia ser um dos tantos estadunidenses que no estrangeiro, a partir do convívio com a bad companny, viria a abalar a sociedade ocidental e cristã dos Estados Unidos.

Ao mesmo tempo, Theo começa a se sentir trocado por Isabelle, a qual, conversando com Mathew, fala de sua ligação com o irmão: foi amor à primeira vista. Levando-se em consideração que são irmãos gêmeos, este amor vem desde o nascimento. Mathew pergunta: ele nunca esteve dentro de você? Isabelle simplesmente responde: ele está sempre dentro de mim. Mostrando que, mais que uma relação carnal, esta é também uma relação psicológica. O ciúme de Theo se manifesta também na conversa subseqüente com Mathew, quando este último agradece por ter sido escolhido para Isabelle, mas Theo lhe diz que não é para ser sempre os três. Agora é a vez de Theo atestar sua ligação com Isabelle dizendo: quando eu disse que éramos siameses, estava falando a verdade.

A relação entre Theo e Mathew é sempre uma relação de tensão: seja pelos códigos culturais específicos de cada um, seja pela disputa de Isabelle, seja pela própria tensão sexual existente entre eles. Quando estão juntos na banheira, uma nova discussão é levantada. Quem é melhor guitarrista? Jimi Hendrix, estadunidense de Seattle, ou Eric Clapton, inglês que foi chamado de Deus, em um grafitti, "Clapton is god", em meados dos anos 1960, quando ainda tocava no John Mayall's Bluesbreakers. Isabelle se junta aos dois na banheira e atenua a tensão: meus pais só transaram uma vez na vida, por isso somos gêmeos, não quiseram fazer duas vezes. Obviamente uma crítica a sexualidade dos pais. Nesse momento, Mathew muda o rumo da conversa e começa a falar que ama os amigos, mas que é sempre ele que toma a iniciativa de falar. 
Theo e Isabelle pedem então uma prova de amor a Mathew: gostariam de depilar seus pelos pubianos. Mathew fica extremamente irritado. Reclama das "obscenidades" dos irmãos, da relação "anormal" entre Theo e Isabelle - algo até então não expressado pelo estadunidense -; também aproveita e indaga porque ela nunca saiu com outro rapaz, demonstrando seu interesse nela e, conscientemente ou não, provocando Theo. Assim, Mathew convida Isabelle para um encontro ao melhor estilo "hollywoodiano": lanchonete, coke, para mais tarde assistir no cinema - agora no fundo e não mais como os cinéfilos - ao filme Sabes o que quero (The girl can't help it, com direção de Frank Tashlin, 1956) com Jane Mansfield e na qual se destaca a música You'll Never Know com o conjunto - mais estadunidense impossível - The Platters.

Voltando do encontro, Isabelle nota que Theo está no quarto com outra mulher; o ciúme a abala. Mathew pede para eles irem ao quarto dela; apesar de alguma relutância da moça, ele está lá ao som de The Spy, dos Doors, e descobre que a Isabelle do quarto não é a mesma que ele conhece. Ela então aparece maravilhosamente caracterizada de Vênus de Milo. Segue-se uma bela cena de sexo oral, interrompida pela fúria de Isabelle ao descobrir que Theo está ouvindo La Mer no quarto ao lado.

Novamente no quarto de Theo, este e o estadunidense voltam a discutir, desta vez regado aos caros vinhos da adega do pai dos franceses. $O$ epicentro da discussão é Mao Tsé Tung, personagem que ilustra um quadro no apartamento e que é mostrado pelo filme em várias cenas, como se estivesse onipresente, e a Revolução Cultural chinesa: ao passo que o francês destaca o teor da revolução, feita com livros e não com armas, o estadunidense portador de uma influência essencialmente liberal - diverge, ao criticar a proeminência e o monopólio de um único livro - O Livro Vermelho - como referência da revolução. Em seu ímpeto liberalizante, com o afloramento dos sentidos e das emoções produzido pelo vinho, Mathew diz que os chineses não passam de figurantes em sua revolução; e que se Theo realmente acreditasse no que dizia, estaria nas ruas de Paris, e não trancado no apartamento. A tensão novamente cresce entre os dois, a tal ponto que o componente homossexual da relação dá a impressão de que será desvelado.

Mas isso não acontece. Interrompidos por Isabelle, os dois não consumam a relação. A jovem francesa dá ares de uma leve repressão - estará também se sentido traída, agora pelo americano? - e os convida a ir à sala, onde tinha montado uma espécie de "tenda" - já que o quarto de Theo não servia mais, por ele ter levado outra pessoa para lá. Insegura por ter quase presenciado a possível relação entre os rapazes, ela pergunta se o amor dos dois era para sempre, obtendo uma resposta afirmativa de Theo. Os três deitados nus são flagrados pelos pais, que deixam um cheque e voltam a sair. Isabelle acorda e fica transtornada ao ver o cheque, vai até a cozinha, liga uma mangueira à instalação de gás e a desenrola até a tenda, disposta a dar um fim em tudo aquilo ali - o que desperta a curiosidade dos espectadores sobre o acontecido, para 
desencadear reação tão radical. Repentinamente, uma pedra quebra a vidraça e os três jovens irrompem para o mundo que existia fora do apartamento - o que, em certa medida, representa a Revolução como a salvação.

O filme encerra com Theo e Isabelle tomando posições de frente no protesto, enquanto Mathew se retira. A música final é Non, Je ne regrette rien (Eu não me arrependo de nada) na voz de Edith Piaf, o que pode ser entendido como uma mensagem de resistência do diretor, já que Bertolucci afirma que quando decidiu filmar Os Sonhadores tinha por ideia principal prestar uma homenagem aos "anos rebeldes" da década de 1960.

Porém, Bertolucci esvaziou muito o significado daqueles anos em sua obra. Deixando aparentemente quase todo o caráter político de lado, dando muito mais ênfase ao triângulo amoroso de Theo, Isabelle e Mathew.

\section{Cinema se Auto-Referencia}

Na película de Bernardo Bertolucci, a elegia ao Cinema e a sua História permeiam toda obra. Como bem observa Mathew: só os franceses para instalarum cinema num palácio. $O$ afinco pela sétima arte era tamanho, que os protagonistas preferiam sentar nas poltronas das primeiras fileiras para receber as imagens primeiro. E o inaugural ato político mostrado pelo filme é o afastamento do diretor da cinemateca Henri Langlois, louvado por rearticular e exibir filmes de todos os gêneros, ao invés de deixá-los arquivados. Esta paixão e fascinação pelo Cinema é atributo marcante da França, como é caracteristicamente peculiar seu relacionamento com a cinematografia estadunidense.

O roteiro de Os Sonhadores é construído com menções, citações e exibições de filmes de grande destaque na História do Cinema. E dos filmes inseridos, sua maioria é estadunidense. $O$ primeiro filme que tem suas imagens apresentadas é Acossado (À bout de souffle, 1960) de Jean-Luc Godard. Isabelle menciona que suas primeiras palavras pronunciadas ao nascer foram: New York Herold Tribune!, ditas no filme pela personagem de Jean Seberg. Godard, tal como Bertolucci, começa a se destacar na sua carreira cinematográfica na década de 1960, constituindo uma geração que rompe com a tradição estética e linguística dominante. O filme de Godard é um dos pontos de partida da Nouvelle Vague, movimento nascido através da Cahiers du cinéma, uma revista que reuniu críticos e especialistas e desenvolveu o conceito de Politique des auteurs, no qual o diretor é responsável por todos os elementos que constituem a produção de um filme. O segundo filme inserido é Rainha Christina (Queen Christina, de Rouben Momoulian, 1933), no qual a grande estrela Greta Garbo interpreta a rainha sueca do século XVII. O terceiro filme é O Picolino (Top hat), musical estrelado por Fred Astaire e Ginger Rogers. O quarto filme é Bande à part (Bande à part, também de Godard, 1964) Posteriormente Monstros (Freaks, de Tod Browing, 1932) cujo enredo retrata uma família de deformados e monstros bizarros. O sexto filme é $A$ Vênus Loira, 
com a diva Marlene Dietrich interpretando uma cantora de cabaré. O sétimo registro é feito a Scarface - $A$ vergonha de uma nação, precursor dos filmes que abordarão o gangsterismo e a máfia, temas caros a Hollywood. O último filme citado é Mouchette - A Virgem Possuída (Mouchette, de Robert Bresson, 1967), adaptação do romance homônimo de Georges Bernanos.

A menção a esses filmes certamente é feita pelo seu estatuto de obrasprimas, alcançado ao longo da História do Cinema. Mas ao analisar os temas retratados, podemos observar que seus enredos se relacionam com a narrativa empreendida por Bertolucci. Acossado, representa uma inversão de papéis de Os Sonhadores, pois Jean Seberg interpreta uma americana que, residindo em Paris, se envolve e esconde um criminoso. Rainha Christina retrata a História da nobre sueca que abdica do trono pelo seu amante. De certa forma, esta é a interrogação que o espectador projeta sobre a possível ação de Isabelle frente a seus dois amores, sendo que a ambigüidade sexual da personagem de Greta Garbo não deixa de se associar a mesma de Isabelle.

O Picolino é um musical, cujo enredo se constitui num mero pretexto para os números musicais protagonizados por Fred Astaire e Ginger Rogers. Tal como Os Sonhadores, o 1968 idealizado não está presente, pois o roteiro enfoca as relações emocionais dos personagens. É importante destacar que a dualidade da relação de Isabelle e Theo, com seu amor e ódio imbricados, é verificada no real e no representado de $O$ Picolino. Ginger Rogers e Fred Astaire protagonizaram um dos casais mais famosos e idealizados das telas, mas na vida real era conhecida a inimizade e o ódio que nutriam um pelo outro.

Essa dicotomia real/representado é trazida à tona na exibição de uma cena de Bande à part, onde o trio central de protagonistas corre pelo interior do Louvre quebrando as regras da ordem (assim como a protagonista do filme que, ao se relacionar com dois ladrões e permitir que assaltem sua casa, quebra as regras sociais e morais dominantes). Mathew hesita reproduzir a cena, pois teme ser deportado. Imediatamente Theo Ihe responde: Se eles não foram pegados, nós não seremos. É o próprio estadunidense que aponta a diferença entre real e ficção. A menção a Freaks insere o estranhamento do tipo de relação vivida pelos irmãos, como sendo algo bizarro, uma aberração. Ela é reforçada numa fala posterior de Theo: Nós somos monstros.

A Vênus Loira aborda a questão do adultério, ao retratar uma cantora de cabaré que aceita o dinheiro de um milionário para custear o tratamento médico de seu marido. O símbolo sexual encarnado na figura de Marlene Dietrich insere a fetichização e o erotismo, também visualizado em Isabelle. A personagem de Dietrich sabe manipular as pessoas para alcançar seus objetivos. Este é o jogo realizado por Theo e Isabelle, que perdem a noção da fronteira entre o desejo e a autonomia. Como aponta Theo sobre os castigos aplicados: Você acha que fazemos isso por obrigação?. E essa manipulação aparece fortemente na cena em que Isabelle obriga Theo a se masturbar diante da foto de Dietrich colada na parede. A manipulação realizada por 
Isabelle para satisfazer seus desejos, os desejos de Theo fluídos de gerações e divas do passado e o comportamento de uma geração, que não hesita em ejacular suas transgressões sobre o passado, ou sobre a imagem do passado.

A cena reproduzida de Scarface mostra uma cruz projetada pelas sombras de objetos como o prenúncio da morte de um personagem. Um recurso que atiça o espectador a procurar essa antecipação nas citações (passadas e futuras) presentes no filme de Bertolucci. Mas a obra de Hawks traz uma menção mais indireta: a questão social e os conflitos do banditismo são colocados em segundo plano diante da paixão que o protagonista desenvolve pela sua irmã, tocando aqui na questão do incesto, tensão sempre constante em Os Sonhadores. Não sabemos se houve a execução do ato sexual entre os irmãos até que Theo tenciona Mathew e Isabelle a fazerem sexo na sua frente. Mathew titubeia, oscila pelo seu moralismo. Para obter a libertação inteira o homem deve "libertar-se ele mesmo do que foi feito de sua vida" (MENEZES, 2001, p. 264-5).

Todavia, esse processo não se isenta de inserir elementos complicadores como a dor relacionada ao sexo. Toda ruptura deixa marcas e, no caso de Isabelle, essa marca é a perda da virgindade, que se correlaciona ao prazer, a dor e a emoção, fatores que não distinguimos em seu olhar e nas lágrimas derramadas após o ato sexual. Ao perceber o defloramento de Isabelle, Theo também instala uma ruptura, ao banhar seus rostos com o sangue, fruto de uma ruptura física que agora transborda para a instância moral e emocional. Se antes era Mathew o analisado, o estudado e explorado, agora esse papel se inverte. Numa longa cena, Isabelle encontra-se deitada, imóvel e nua. Theo inicia um passeio sensorial pelo seu corpo, onde a câmera, afobada, antecipa sua trajetória e é obrigada a retornar. Mais atenta, junto com Mathew, ela analisa cada pêlo e cada poro de Isabelle. Seu corpo preenche todo espaço enquadrado, a ponto de dar a impressão que fugirá para fora da tela. Mathew chupa o dedão de Isabelle, apreciando-o sofregamente. Desliza para seus tornozelos roliços, para suas pernas curvilíneas, mira sua vagina volumosa, aspira seu cheiro incipiente e observa seus pêlos não depilados. Segue para seu ventre convidativo, seus seios fartos e seus mamilos extensos, róseos e salientes. Não resiste a seus lábios que afloram e atraem em conjunto com seus olhos de ressaca. A penetração cultural se dá agora em todas as instâncias e Mathew passa a tentar controlar o ambiente, seu modo de produção e seu funcionamento do cotidiano.

Após uma noite de álcool e devaneios, o trio se refugia numa tenda armada na sala do apartamento por Isabelle. Quando seus pais se deflagram com os três nus e abraçados, o silêncio é a principal reação. Isabelle acorda e percebe o cheque deixado sobre a mesa como consolo. Sua reação ante a descoberta é o suicídio. Aqui, é inserida a cena final de Mouchette, quando a protagonista rola colina abaixo, pondo fim a sua vida. No filme de Bresson, a menina vive numa comunidade rural, sendo desprezada pelo pai e somente a mãe, doente, lhe dá alguma atenção. Cabe a ela o fardo de cuidar da casa e do irmão, também doente. Ela mantém um relacionamento com um homem 
que a usa como álibi para encobrir um assassinato. A ambiguidade deste relacionamento (e da cena de estupro de Mouchette) e do que é apresentado por Bresson, se correlaciona com a cena de Os Sonhadores. Não sabemos o que houve com os três, mas o peso recaído sobre Isabelle leva-a à medida extrema do suicídio. Profundamente marcado pelo jansenismo, que atribui um destino e uma predestinação aos homens, a obra de Bresson insere o questionamento aos sonhadores: até onde vai nossa capacidade de se isentar de tudo o que está em nossa volta? A pedra que invade o quarto traz o político para a ação dos personagens. A Revolução se apresentava como necessária. "A rua invadiu o quarto" exclama Isabelle. É dado o sinal para a saída do apartamento.

Outras menções podem ser visualizadas através dos cenários do filme. No cinema, diversas películas são exibidas rapidamente no início da história. Também diversos cartazes são visualizados nas paredes, ganhando destaque $A$ Chinesa (Le Chinoise, 1967), de Godard, curiosamente um filme símbolo sobre 1968, seja pela sua antevisão aos acontecimentos em Nanterre, seja por toda sua simbologia, não tendo suas imagens exibidas, talvez pela diferença de abordagens pretendida de cada cineasta.

Outro símbolo iconográfico é o rosto de Marilyn Monroe colado sobre o quadro de Eugene Delacroix: A Liberdade Guiando os Povos. A musa máxima produzida pelo cinema estadunidense é sobreposta a um símbolo fundacional da cultura francesa e de sua iconografia. Outra dimensão em que está presente o Cinema é a idealização do romance que Mathew tenta introjetar em Isabelle, ao levá-la para um encontro tradicional: cinema, beijos e mãos dadas. Mas a descoberta e a invasão de Mathew ao quarto - até então não mostrado - de Isabelle, somado aos gemidos e gritos de outra mulher e de seu irmão, ouvidos pelo apartamento, quebram a vivência da representação idealizada.

Junto às visualizações fílmicas e iconográficas, também se discute e se fala sobre o Cinema. E essa questão está marcado pelo debate entre os diferentes ponto-de-vista do europeu, anteposto ao estadunidense. Discussão mais acalorada ocorre entre as preferências por Charles Chaplin e Buster Keaton. Theo acusa os estadunidenses de não compreenderem sua própria cultura.

\section{Paris, Maio, 68}

Embora o ano de 1968 esteja relacionado muito mais com o "espírito de uma época" do que com o ano propriamente dito, é inegável que um dos acontecimentos mais espetaculares e expressivos dessa época ocorreu em maio daquele ano. O Maio Francês não apenas pode ser identificado como um dos maiores símbolos da contestação à sociedade capitalista de pósguerra, mas também pode - e freqüentemente o é - ser colocado ao lado de convulsões sociais de amplitudes revolucionárias. Assim, o Maio Francês se insere como legítimo herdeiro de 1789, 1830, 1848 e 1871. Se as barricadas estudantis não foram capazes de apear a classe dominante do poder, como na 
Revolução Francesa, ou declarar a comuna livre, como em 1871, foi muito mais por contingências históricas do que por diferenças significativas no ímpeto revolucionário. É nesse quesito que se diferenciam os acontecimentos de Paris daqueles de Praga, do Rio de Janeiro e de alhures. Se os estudantes tchecos lutavam pelo afrouxamento das relações stalinistas e os brasileiros reagiam contra uma ditadura brutal, os jovens franceses, portadores da cultura revolucionária de seu país, propugnavam uma subversão política, social, econômica e cultural. No entanto, o Maio de 68 não pode ser entendido como uma explosão estudantil de caráter limitado. Tampouco pode-se atribuir a derrota do movimento revolucionário à imaturidade dos estudantes, como fica subentendido no filme de Bertolucci.

Os condicionamentos necessários para tal explosão vinham sendo estabelecidos nos anos pós Segunda Guerra Mundial. Entre as insatisfações da sociedade francesa, poderíamos nos debruçar sobre a política monetarista da V República, fundada pelo General De Gaulle, em 1958, que arrochava salários dos trabalhadores. No plano internacional, a França passava pelo trauma da descolonização e o governo era pressionado tanto pelos conservadores inconformados pela perda das colônias, quanto pela juventude progressista e/ ou revolucionária que crescera entre o arcaísmo da sociedade metropolitana. A esses problemas gerais, soma-se a contestação estudantil frente à ofensiva governamental no plano educacional. Conforme Robert Ponge (1998, p. 32), a reforma universitária causou frustração e descontentamento generalizado entre os estudantes franceses. $O$ estopim que desencadeou a revolta foi uma manifestação, que, por seu conteúdo e amplitude, estava destinada não apenas a um ato isolado, mas também ao fracasso de suas reivindicações. Os estudantes, insatisfeitos com a péssima localização do recém-criado campus de Nanterre e com os conseqüentes problemas burocráticos advindos do descaso do governo com questões essenciais, como o adequado aparelhamento de uma moradia estudantil, organizaram um ato pacífico e reivindicatório. A reação do governo, que responsabilizava "pequenos grupúsculos" pelas manifestações, foi de repressão e fechamento do campus. Um dia depois, em 3 de maio, no prédio central da Universidade de Paris, a Sorbonne, os estudantes organizaram um ato de repúdio à atitude do governo. A reação foi ainda mais violenta, com a invasão policial e a prisão dos manifestantes. Desde a ocupação nazista, a polícia não ocupava a Sorbonne. Os estudantes protestaram e tomaram o bairro estudantil - Quartier Latin - em manifestações de protesto. Novamente a polícia agiu com brutalidade, prendendo e espancando centenas de estudantes. Mais de 500 estudantes foram presos e muitos foram julgados e condenados sumariamente.

Ao contrário do que pretendia o governo, a escalada repressiva não amorteceu as manifestações estudantis. Muito antes pelo contrário. Nos dias que se seguiram, os protestos aumentaram e os confrontos com a polícia eram cada vez mais freqüentes. A população passou a repudiar a brutalidade policial e o Partido Comunista Francês (PCF) foi pressionado a se posicionar. A posição inicial 
do PCF, que controlava a maior central sindical do país - a Confederação Geral do Trabalho (CGT) - era de que os estudantes provocavam o enfrentamento. Entretanto, estava claro que as barricadas e os enfrentamentos eram fruto de uma reação estudantil frente à repressão policial.

No sábado, dia 11, a União Nacional de Estudantes Franceses (UNEF) e as centrais sindicais chamaram uma paralisação nacional para o dia 13. O governo, acuado, suspendeu as punições e anunciou a reabertura da Universidade. Todavia, a semente da revolta já havia sido plantada e no dia 13 teve início a maior greve da História Francesa, que colocou em xeque o governo De Gaulle. De solidariedade aos estudantes, os manifestantes passaram a uma atitude reivindicatória e desta para o plano político. Os trabalhadores exigiam a redução da jornada de trabalho para 40 horas sem prejuízo salarial, mas não hesitavam em gritar "fora De Gaulle". Bandeiras rubro-negras tremulavam nas ruas de Paris e a Revolução era uma possibilidade, quando dez milhões de trabalhadores paralisaram a França. As esperanças revolucionárias repousavam tanto no movimento operário, que aderira maciçamente à greve, quanto no movimento estudantil - identificado por Herbert Marcuse (1987) como uma vanguarda capaz de impulsionar a Revolução. Além disso, a reação, como era de se esperar, não se fez presente, nem discursivamente, e muito menos com repressão. O fascismo parecia derrotado e os conservadores estarrecidos. De Gaulle estava na beira do abismo e um simples empurrão poderia dar cabo à $V$ República.

Se as condições eram essas, por que o movimento de maio de 1968 foi derrotado? A explicação está na incapacidade da esquerda em dar o tiro de misericórdia no governo De Gaulle. O General, que obviamente não entregaria o poder facilmente, propôs uma solução eleitoral. Segundo o governo, ou os grevistas aceitavam as eleições, ou a polícia - e o exército - restabeleceriam a ordem. Em outras palavras, era o fim da greve e das manifestações ou a guerra civil. É possível, e até provável, que tenha sido um blefe. Entretanto, as forças políticas e sindicais aceitaram prontamente a proposta governamental. Quando nada porque o PCF e a CGT a muito haviam incorporado a palavra eleições ao seu vocabulário combativo em detrimento da palavra Revolução. A urna era a arma menos dolorosa, e ao final, a que se revelou mais eficiente para a virada gaullista. Apostaram nas eleições, que normalmente é vencida por quem as organiza, e perderam tudo, inclusive sua pauta reivindicatória. Aos estudantes, sobrou a etiqueta de provocadores da desordem e, como se não bastasse, 50 anos depois, a culpa da derrota em certas interpretações...

\section{Concluindo}

A visão contemporânea sobre o 68, produzida por Bernardo Bertolucci, tem na negação das relações humanas constituídas até então sua maior característica. Isso fica evidente nas orgias quase desesperadas no apartamento - o que ofusca as ruas sendo tomadas pelos revolucionários na melhor 
tradição dos antigos communards -, ao mesmo tempo em que antecipa o slogan clássico da contracultura, "faça amor, não faça a guerra". As cenas de sexo, quase diuturnas, mal eram interrompidas para liquidarem as garrafas de vinho da casa. Sequer a chegada dos pais, que presenciaram perplexos os três amigos dormindo juntos de uma forma que mal podiam diferenciar os membros de uns e de outros, foi capaz de interromper o desregramento em que estavam; por iniciativa do próprio pai, o casal se retira, não sem antes deixar uma "mesada" para os filhos. De certa maneira, estaria aqui embutida uma crítica a uma juventude bem nascida, fortemente radicalizada, mas que dependia economicamente dos seus maiores e disto não abria mão; ou seja, um "radicalismo pequeno-burguês".

Seja por cansaço ou por conta dos estímulos que, cada vez mais e fortemente, vêm da rua e penetram no apartamento isolado, os três jovens saem de seu isolamento e se misturam aos revoltosos, partindo para o enfrentamento direto com a repressão policial. Seria esSa a mensagem final desejada pelo diretor? Ou seria a revolução vivida nas ruas uma utopia tão legítima quanto aquela experimentada no refúgio em que se esconderam, para praticar todos os atos desejados? O filme começa e termina na revolução das ruas, mas dedica-se bem mais à exploração da revolução nos corações e mentes. Se na esfera política a revolução não venceu, gerou mudanças profundas nas esferas cultural e comportamental.

Nessa época, sexo e reprodução, passam a ser mais dissociados anteriormente, eram tratados como uma única ação. A partir daí, existe uma maior liberdade com relação ao prazer, principalmente feminino; as práticas sexuais ditas "anormais", tais como a masturbação e o sexo oral, passam a ser mais incentivadas. $O$ corpo começa a ser visto de outra forma, não mais algo para ser ocultado, mas sim para ser admirado e também utilizado como forma de expressão. É a época de uma melhor compreensão da sexualidade feminina. Com os métodos contraceptivos, as mulheres podem se prevenir com relação a gravidezes indesejáveis, têm uma maior liberdade em relação ao ato sexual, podem sentir prazer sem maiores preocupações. Bertolucci envereda por este viés, o da sexualidade e sensualidade, o que não "arruína" o filme, mas peca ao deixar de fora da sua pretensa homenagem aos anos sessenta outros aspectos fundamentais para uma melhor compreensão daqueles tempos.

O filme se encerra com Mathew se decepcionando com seus amigos incestuosos, no único momento em que os sonhadores resolvem encarar a realidade, a qual, literalmente, havia entrado janela adentro, a fim de lhes salvar a vida. Mathew abandona os irmãos por acreditar que o coquetel molotov nada mais é do que fascismo engarrafado e que aquela atitude os rebaixaria ao mesmo nível da burguesia reacionária. Portanto, estariam fadados ao fracasso, tanto político, quanto moral. Nada mais longe da realidade para o jovem Mathew de 1968, que na sua visão contemporânea pode ser Bernardo Bertolucci. 
Por fim, se as propostas revolucionárias de 68 foram derrotadas, é preciso ter no horizonte que "a derrota da revolução de 68 , a derrota parcial e o bloqueamento do processo revolucionário de 68 possibilitaram uma vitória histórica da barbárie e quando se fala histórica, devemos reconhecer que é uma vitória temporária, limitada no tempo, que tem vida e que vai terminar. Uma vitória que como é histórica é prenhe de contradições, de limites e de possibilidades para o futuro" (RIBEIRO, 2003, p. 124). O que pode ser depreendido da cena final do filme, quando é apresentada uma grande barricada, pois não é menos verdade que "a barricada fecha a rua, mas abre o caminho".

\section{Referências:}

BERTOLUCCI, Bernardo. Entrevista com Luis Carlos Merten. O Estado de São Paulo. São Paulo, 6/12/2004.

MARCUSE, Herbert. El hombre unidimensional: ensayo sobre la ideologia de la sociedad industrial avanzada. $2^{\mathrm{a}}$ ed. Barcelona: Ariel, 1987.

MENEZES, Paulo. À meia-luz. Cinema e sexualidade nos anos 70. São Paulo: Ed. 34, 2001.

PONGE, Robert. Maio de 1968: um mês que abalou a França. In: PONGE, Robert (org). 1968: o ano das muitas primaveras. Porto Alegre: Unidade Editorial, 1998.

RIBEIRO, Luiz Dario Teixeira. Reflexões sobre 68. In: HOLZMANN, Lorena; PADRÓS, Enrique Serra. 1968: contestação e utopia. Porto Alegre: Editora da Universidade (UFRGS), 2003.

TRUFFAUT, François. O cinema segundo François Truffaut. Textos reunidos por Anne Gillain. Rio de Janeiro: Nova Fronteira, 1990. 